\title{
Inshore circulation and transport of herring larvae off the north coast of Scotland
}

\author{
M. R. Heath, P. M. MacLachlan, J. H. A. Martin \\ Marine Laboratory, PO Box 101, Victoria Road, Aberdeen AB9 8DB, Scotland
}

\begin{abstract}
A patch of herring larvae Clupea harengus L. was located off Cape Wrath (north coast of Scotland) on 23 Aug 1985 and its movements tracked for $13 \mathrm{~d}$. The trajectory was first eastwards to approximately $3^{\circ} 45^{\prime} \mathrm{W}$ and then northwards up the west side of the Orkney Isles. Hydrographic, current meter and drifting buoy measurements indicated that significant variation in the circulation regime of the inshore waters between Cape Wrath and the Orkney Isles occurred during the tracking period, and these were clearly reflected in the drift trajectory. Repeated sampling of a fixed line of stations over a 4 mo period from August to November indicated that larvae were retained in the inshore region off the north of Scotland but were rapidly dispersed from areas further offshore
\end{abstract}

\section{INTRODUCTION}

Numerous instances of correlations between hydrographic conditions in fish spawning areas and the survival of larval stages are documented in the literature (see Bakun 1985 for a review). However, the relationship between environmental variability and survival of larvae of Atlantic herring Clupea harengus L. in northeast Atlantic waters remains undefined despite the massive fluctuations in recruitment to stocks of this species, particularly in the North Sea, in recent years (Corten 1986). In 1984, we commenced investigations on the relationship between survival of herring larvae and inshore circulation regimes around the Scottish coast. The first investigations were carried out on newly hatched larvae from a major spawning ground on the Hebridean Shelf (Heath \& MacLachlan 1987). This paper describes the continuation of these investigations in 1985. The long-term objective of the research programme is to assess the extent to which the survival of herring larvae on the northwest European Shelf is dependent upon circulation patterns, with a view to accounting for at least some of the massive recruitment variability observed in herring stocks in this area.

Herring larvae hatched during the autumn on the west side of Scotland are carried by the clockwise residual circulation around the north of Britain and contribute to juvenile populations in the North Sea. This finding was based originally on observations of larval distribution (Wood 1971) and also inferred from the results of the Bloden tagging experiment (Anon. 1975) as well as parasite prevalence data presented by MacKenzie (summarised by MacKenzie 1985) which showed that the adult herring populations in the Hebrides area contained a large proportion of individuals derived from nursery areas in the eastern North Sea. More recently, Heath \& Walker (1987) presented evidence based on gene frequency data that populations of recently hatched larvae sampled during September and October to the north and west of Scotland contributed to populations sampled in the North Sea in February of the following year.

The mechanism by which larvae are transported into the North Sea from areas to the west has been identified as the Fair Isle Inflow - an extension of the west of Scotland coastal current (Ellett \& Edwards 1983) which enters the North Sea between the Orkney and Shetland Isles (Dooley 1981). Dooley \& McKay (1975) demonstrated that this current had the potential to carry larvae from the Hebrides into the North Sea within a few weeks, and Heath et al. (1985) showed a clear association between the distribution of larvae and the core of the current in the inflow region east of the Orkney Isles.

Approximately half of the west of Scotland herring stock spawns to the west of the Hebrides, and Heath \& MacLachlan (1987) showed that larvae from this area are entrained into the coastal current. Most of the remainder spawn well inshore of the main current 
stream off the north coast of Scotland (Rankine 1986) and the transport route of larvae from this area has not been convincingly identified. Ramster et al. (1973) reported data on drift markers released off Cape Wrath and in the western end of the Pentland Firth. On the basis of these results they concluded that larvae hatched inshore of the main current flow were probably carried through the Pentland Firth into the North Sea. However, Dooley \& Mackay (1975) concluded, on the basis of rather limited current meter data, that there was no significant transport towards the Firth from the area west of Orkney.

The hydrography and circulation between Cape Wrath and Orkney has received very little attention from oceanographers, other than occasional mapping of physical variables (Johnston \& Craig 1953, Craig 1959, Ramster et al. 1973). However, the main conclusion of such studies has been that a sharp boundary between Atlantic water (salinity greater than $35.1 \mathrm{ppt}$ ) and inshore water is generally located approximately $30 \mathrm{n}$ mile $(55 \mathrm{~km})$ west of Orkney, following the $100 \mathrm{~m}$ isobath. Dooley \& Mackay (1975) concluded that the 'Fair Isle Current' exists in the boundary region as a narrow ( 8 to $10 \mathrm{n}$ mile [ 15 to $18 \mathrm{~km}$ ] wide) high velocity ( $>5 \mathrm{n}$ mile $[9 \mathrm{~km}] \mathrm{d}^{-1}$ ) topographically steered flow. Surprisingly, there have been very few attempts to measure the flow rate or variability in this current, and even fewer studies of circulation inshore of the current zone. The importance of the area as a herring spawning ground combined with the lack of understanding of the circulation pattern were the main considerations in our decision to concentrate our investigations in 1985 on the area between Cape Wrath and the Orkney Isles. As far as we are aware, the studies reported here are the first to describe the circulation pattern in the inshore region.

\section{MATERIAL AND METHODS}

Physical and biological data in the area $58^{\circ} 30^{\prime}$ to $59^{\circ} 30^{\prime} \mathrm{N}$ and $3^{\circ} 00^{\prime}$ to $5^{\circ} 00^{\prime} \mathrm{W}$ were collected during 2 cruises by FRV Clupea (31 Jul to 15 Aug 1985; 21 Aug to 10 Sep 1985), and 3 by FRV Scotia (6 to 26 Sep 1985 ; 4 to 24 Oct $1985 ; 1$ to 21 Nov 1985).

Plankton sampling was carried out during all cruises except the first of the series aboard FRV Clupea.

High speed net. The Gulf III high speed net (Gehringer 1952) was used to collect herring larvae and plankton on all cruises where plankton sampling was performed. The gear was operated in a double oblique tow to within $5 \mathrm{~m}$ of the seabed, in accordance with the guidelines of the ICES International Herring Larval Surveys. The mechanical flowmeter was calibrated by carrying out tows at a constant depth and speed over a measured distance with the net removed from the sampler. The efficiency of the sampler is known from flume tank tests to be 0.86 (Wood \& Nichols 1983).

Drum net. A $1 \mathrm{~m}$ diameter drum net (half of a Bongo pair) fitted with a $250 \mu \mathrm{m}$ mesh conical net and a 2 I live bucket was used as the main sampling tool during the 21 Aug to 10 Sep cruise by FRV Clupea. The gear was deployed in a double oblique tow at 2 to $2.5 \mathrm{kn}$ to within 3 to $5 \mathrm{~m}$ of the seabed. This sampler was used in preference to the high speed net in order to obtain samples of herring larvae in good condition. The volume sampled during each tow was measured using a TSK flowmeter mounted inside the drum which was calibrated in a similar manner to that described for the Gulf III sampler.

The efficiency of the drum net was determined by performing 4 replicate tows to within $5 \mathrm{~m}$ of the seabed next to a drifting buoy located in the centre of a patch of herring larvae, with both the drum net and the Gulf III. Taking the material caught per $100 \mathrm{~m}^{3}$ filtered by the Gulf III as the standard, the efficiency of the drum net was given by: Conc $\mathrm{Drum}_{\mathrm{m}} \mid \mathrm{ConC}_{\mathrm{Gulf}}$.

The exercise was repeated at approximately midnight and midday on 4 to 5 Sep and, based on the displaced volume of plankton caught, the efficiency of the drum net was 1.78 during darkness and 1.49 at midday. Since these values are greater than 1.0 , it seems likely that material was extruded through the meshes of the high speed net to a greater extent than in the low speed net. The estimated efficiencies were sufficiently similar for any diurnal effect to be ignored, and the mean efficiency of 1.64 was used when comparing plankton volume data from the 2 types of gear. However, with respect to catches of herring larvae, the efficiency of the drum net was 0.69 at night, and 0.22 at midday. In this case, the 3-fold decrease in efficiency at midday must represent visual avoidance of the net by the larvae (median length approximately $11 \mathrm{~mm}$ ). To account for visual avoidance in calculating the concentration of herring larvae from drum net catches the efficiency was assumed to vary according to a sine function over a $16 \mathrm{~h}$ day, this being a reasonable model of the diurnal variation in light intensity at the time of the investigations. At night, the background efficiency of 0.69 was used. Thus, the efficiency $(k)$ was given by:

$$
k=0.69-(\sin (A) \times 0.47)
$$

where $A=0$ radians at $0400 h, A=\pi / 2$ radians at $1200 \mathrm{~h}$, and $\mathrm{A}=\pi$ radians at $2000 \mathrm{~h}$ (all times GMT).

Isaacs-Kidd net. During the plankton sampling carried out in late November the expected length range of herring larvae was such that there was a possibility of under-representation of the larger end of the range in catches taken with the Gulf III. To minimise this possibility, sampling was restricted to night. 
time, and as a further check replicate tows with an Isaacs-Kidd mid-water trawl fitted with a $500 \mu \mathrm{m}$ codend were carried out at each sampling position. The length distributions of larvae caught by the 2 gears at each station were not significantly different, and taking all the sampling stations together the numbers caught per minute towing with the Isaacs-Kidd net were approximately in proportion to the number per $100 \mathrm{~m}^{3}$ calculated from the Gulf III catches.

Treatment of plankton samples. All net-caught samples were preserved in a buffered $4 \%$ formaldehyde solution. Samples collected aboard FRV Clupea between $21 \mathrm{Aug}$ and 10 Sep were first rinsed with fixative and then resuspended in seawater. All herring larvae were immediately picked out and preserved in a vial of $4 \%$ formaldehyde solution. The remaining plankton was preserved separately.

On return to the laboratory the displaced volume of all net-caught plankton was estimated as the volume difference between a suspension in water and the filtrate passing through a $60 \mu \mathrm{m}$ mesh net. The standard length of all herring larvae caught was measured to the nearest $0.1 \mathrm{~mm}$.

\section{Hydrographic sampling.}

Physical variables. During all cruises except the first aboard FRV Scotia, surface temperature and salinity were recorded from the ship's pumped seawater supply using a thermosalinograph (NBA Controls Ltd TDS-6). These data, along with time and Decca-derived positional information were recorded at 10 min intervals using an Acorn BBC microcomputer. On return to the laboratory, the temperature and salinity data were corrected using calibration data collected during each cruise. Surface salinity samples and temperature data from a hull-mounted thermistor were collected on a $10 \times 10 \mathrm{n}$ mile $(18.5 \mathrm{~km})$ grid during the cruise by FRV Scotia when the thermosalinograph was not available.

Full hydrographic sampling was carried out during both cruises by FRV Clupea and from FRV Scotia in November. Between $21 \mathrm{Aug}$ and $10 \mathrm{Sep}$, and during November, data were collected using a CTD (Conductivity-Temperature-Depth meter; NBA Controls Ltd, Model TDS-7M) interfaced to an Acorn BBC microcomputer. Surface calibration samples were collected at every cast and in most cases a cast of reversing bottles was also performed for sub-surface calibration. During the first cruise in August only reversing bottle data were collected. On return to the laboratory the CTD data were sorted according to depth, filtered to remove anomalous values, and corrected using appropriate calibration factors. The stability parameter $\phi\left(\mathrm{J} \mathrm{m}^{-3}\right)$ described by Simpson \& Pingree (1978) was calculated from the density $\left(\sigma_{t}\right)$ at each observation depth.

Current meters. Four current meter moorings were deployed during the first cruise aboard FRV Clupea and recovered during October. The moorings were of a conventional ' $U$ ' type and each had an Aanderaa current meter suspended at a depth of $30 \mathrm{~m}$ below a sub-surface float. Two of the moorings were in water deeper than $100 \mathrm{~m}$ and these had an additional meter at approximately $80 \mathrm{~m}$.

Drogue buoys. Five drifting buoys were deployed between 21 Aug and 10 Sep. The construction of the buoys was described by Dooley (1974), and consisted of a surface buoy equipped with a flashing light and radar reflector, with an $8.5 \mathrm{~m}$ parachute attached approximately $30 \mathrm{~m}$ below the buoy on a weighted $4 \mathrm{~mm}$ wire.

\section{Survey strategy.}

Fixed station surveys. During all surveys sampling was carried out on a pre-determined grid of positions spaced at approximately $10 \mathrm{n}$ miles $(18.5 \mathrm{~km})$. The measurements performed varied from survey to survey, but in most cases included hydrographic and plankton sampling. The purpose of this sampling regime was to determine the distribution of variables over a wide area.

Patch surveys. Between 21 Aug and 10 Sep several small scale surveys of a patch of herring larvae were carried out. Each survey contained approximately 10
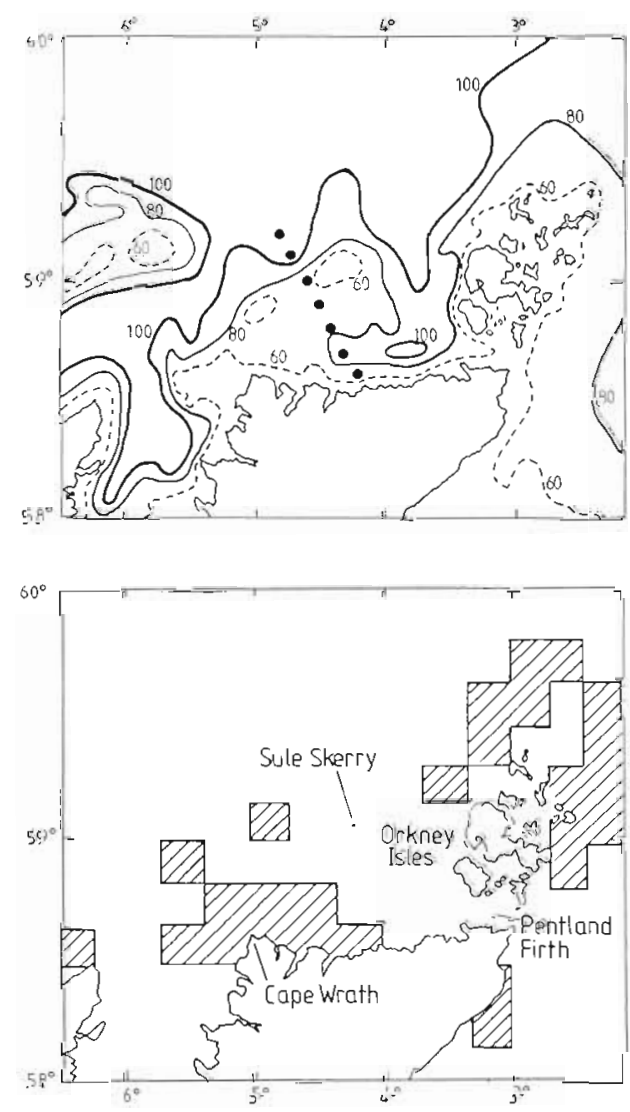

Fig. 1. (a) Bathymetry and positions of standard sampling positions off the north of Scotland. (Isobaths in metres). (b) Distribution of herring spawning areas off the north of Scotland (from Rankine 1986) 
stations and lasted between 6 and $8 \mathrm{~h}$. The objective was to complete a pair of orthogonal lines of stations intersecting at the centre of the patch. The first few stations were always positioned on the basis of some prior knowledge concerning the location of the patch, but no decision on further positions was taken until estimates of the concentration of larvae were calculated from the initial stations.

Tidal correction of patch survey sampling positions. The scale of the patch surveys was such that the distance between sampling positions was generally less than the tidal excursion. All patch survey sampling positions were therefore corrected using hourly mean current velocities recorded at the nearest current meter mooring in each case, with reference to the time of collection of the first sample in the survey. This was performed by calculating the vector displacement from the mooring position for all sampling times and then subtracting these vectors from the sampling positions. In instances where individual patch surveys were combined to form a single coverage, the reference time for tidal correction was the time of the first sample of the first survey included in the coverage.

\section{RESULTS}

\section{General observations}

The bathymetry and general distribution of herring spawning grounds around the north of Scotland (from Rankine 1986) are shown in Fig. 1. Surface hydrographic data from this area show the same general features throughout the year. The $35.0 \mathrm{ppt}$ surface isohaline approximately follows the $100 \mathrm{~m}$ isobath whilst isohalines in the range 34.8 to 35.1 are generally very closely spaced indicating a strong density gradient and a high velocity shear (Fig. 2). In the summer, thermal stratification may extend over a wide area except within a few miles of the coast, in the Pentland Firth, and around the Orkney Isles where maximum tidal current speeds exceed $2 \mathrm{~m} \mathrm{~s}^{-1}$.

The average $25 \mathrm{~h}$ residual current vectors at each of the 4 current meter moorings deployed in 1985 are shown in Fig. 3. Also shown in this figure are the average vectors from records collected during August 1974 and previously reported by Dooley \& MacKay (1975). The percentage stability indicates the consis-

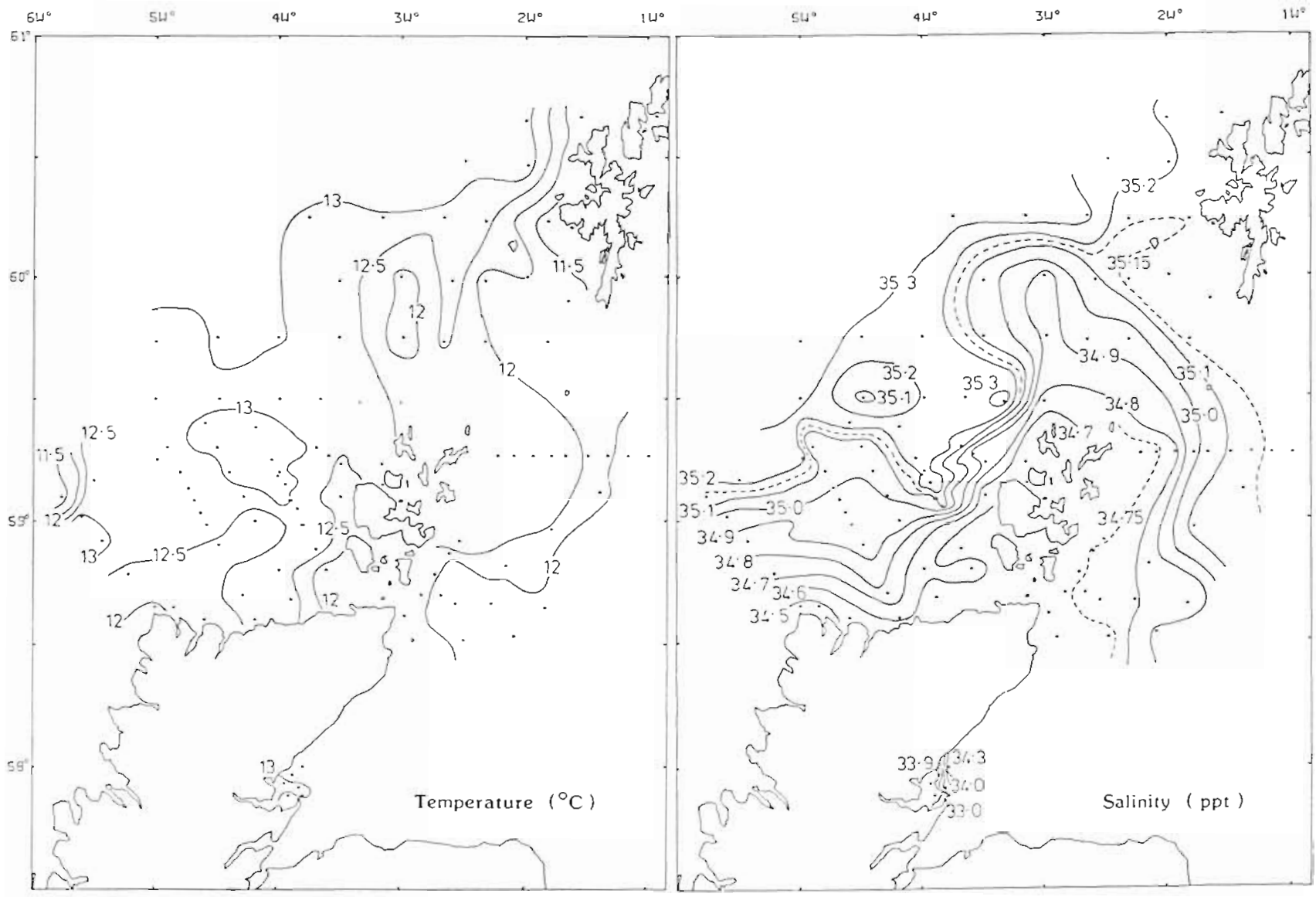

Fig 2. Distribution of surface temperature and salinity off the north of Scotland during August 1985 
tency of each of these vectors. These data emphasise the differences in current speed in the area, and identify the consistent topographically steered current flowing approximately along the $100 \mathrm{~m}$ isobath. Currents south of Sule Skerry are generally weak and variable, except close to the mainland coast where the data indicate a persistent longshore current.

\section{Variability over the autumn period}

Variability over the autumn period was investigated by repeated sampling along a standard survey line (Fig. 1) over a 4 mo period from August to November 1985. The minimum data collected on each occasion were surface temperature and salinity. On all occasions except during early August, plankton sampling was carried out, whilst in August and November CTD and water bottle casts were performed. Results from the standard line surveys (Fig. 4) indicated that the breakdown of thermal stratification occurred during early September. High concentrations of plankton were present in both the stratified offshore region and the inshore regions during August and early September, but the concentration declined rapidly in the offshore area during late September. The breakdown in thermal stratification coincided with a decrease in salinity and with the period of highest abundances of herring larvae in the inshore region. This period also coincided with the peak hatching period of herring larvae in the inshore region since the smallest larvae were caught at this time. Larvae persisted in high concentrations until late November at the inshore stations, but this could not have been due to later hatching since the median length increased steadily throughout the survey period. In the offshore region north of $59^{\circ} 00^{\prime} \mathrm{N}$, catches of larvae with a median length smaller than $8 \mathrm{~mm}$ were found only at the

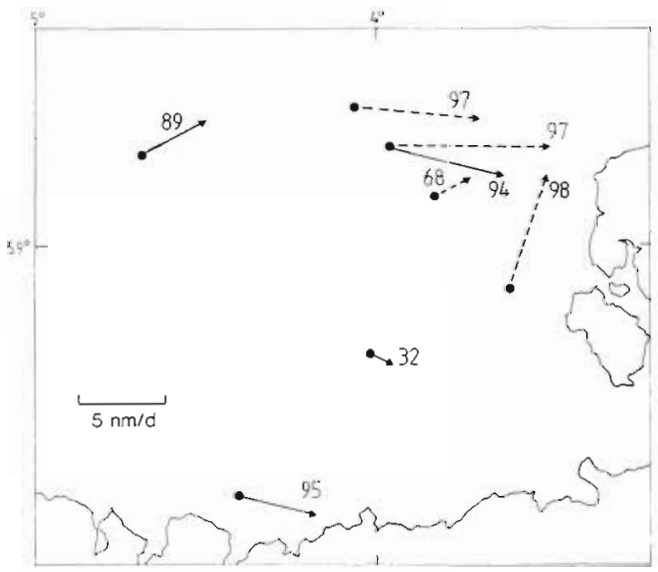

Fig. 3. Long-term $25 \mathrm{~h}$ residual currents at moorings located off the north coast of Scotland. $\rightarrow: 2$ Aug to 18 Oct $1985 ;-\rightarrow: 8$ to 26 Aug 1974. Values alongside the arrows represent the percentage stability of each record end of August in small numbers. Highest concentrations occurred in mid-September but these were of larger sizes (median length 9 to $10 \mathrm{~mm}$ ) indicating that they had been carried into the area from some distance upstream. Concentrations declined very rapidly after the end of September, indicating that dispersal was more rapid offshore than in the inshore region.

\section{Patch tracking experiment}

Between 23 and 25 Aug 1985 a general survey of the study area was carried out. The highest concentrations of herring larvae were found on 23 Aug on the western edge of the area and along the coast within 5 to $10 \mathrm{n}$ miles ( 9 to $18 \mathrm{~km}$ ) of the shore (Fig. 5).

On 27 Aug detailed patch-survey work commenced, the first sampling stations being positioned on the basis of a presumed drift rate of $3 \mathrm{n}$ mile $(5.5 \mathrm{~km}) \mathrm{d}^{-1}$ (typical for other inshore areas west of Scotland) projected eastwards from the position of the highest concentration of larvae during the general survey. Following the procedure described earlier for patch surveying, a complex of small patches was mapped and the results, after correction of sampling positions for tidal displacement during the survey, are shown in Fig. 5. Three centres of high concentration were located, each being distinguishable on the basis of the length distribution of the larvae (Fig. 6). Two of these centres were represented
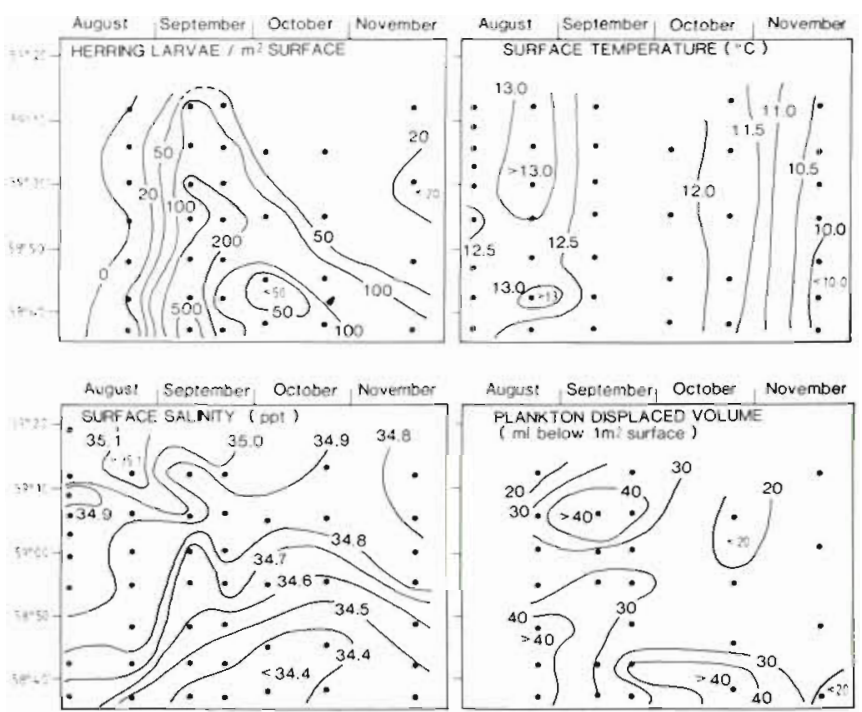

Augus: September October November

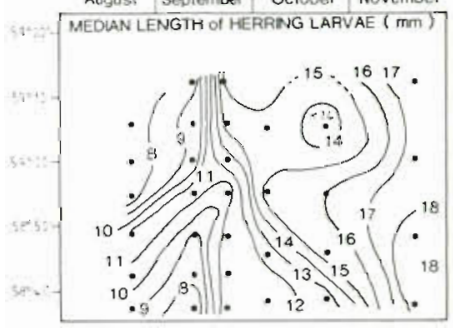

Fig. 4. Changes in physical and biological observations made along the standard survey line between August and November 1985 


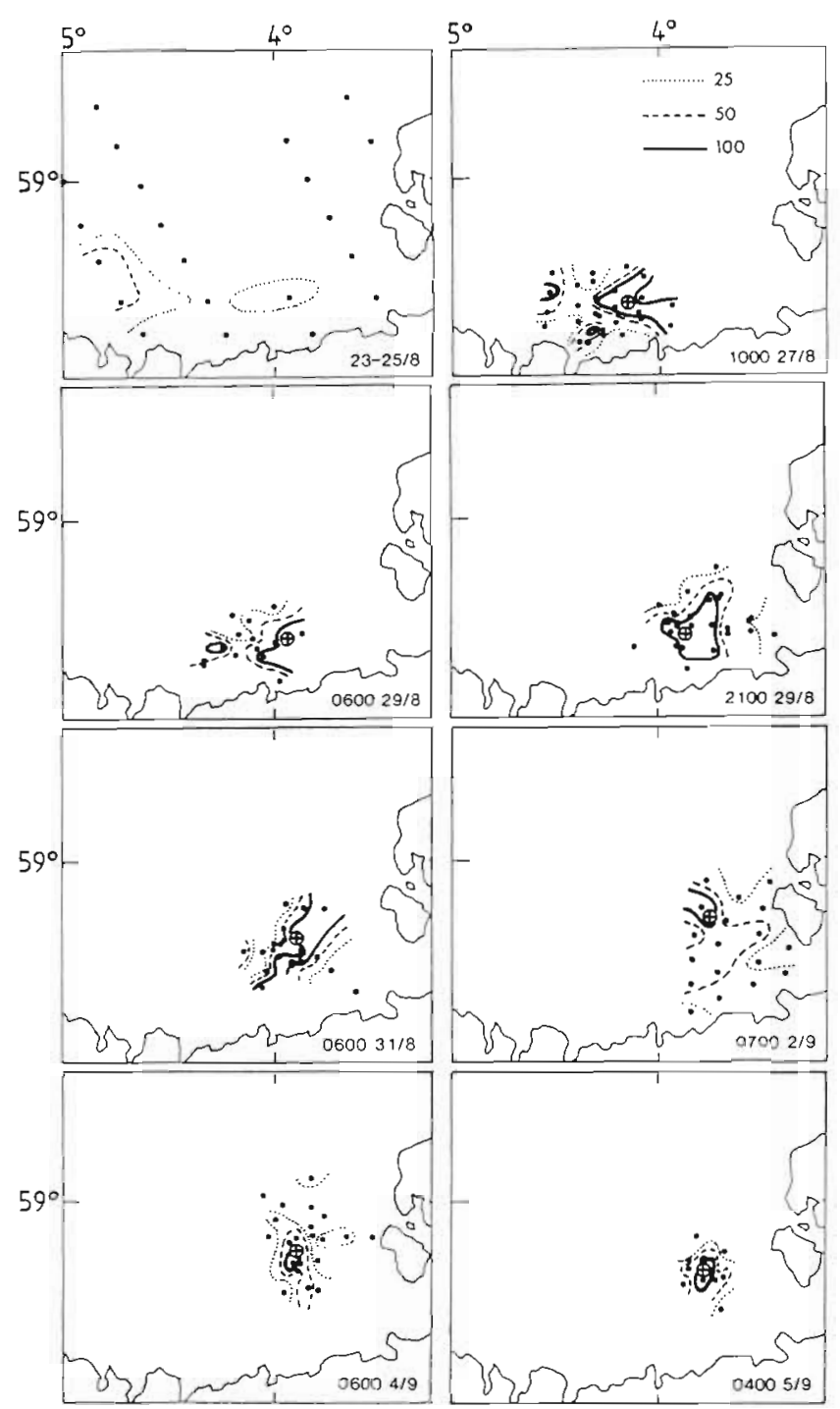

Fig. 5. Clupea harengus. Distributions of herring larvae (number $\mathrm{m}^{-2}$ ) during surveys carried out between 23 Aug and 5 Sep 1985. Except for the first survey, all sampling positions have been corrected for tidal displacement during the surveys.

$(\oplus)$ Centre of mass of the target patch on each coverage

by only one sample containing more than 100 larvae $\mathrm{m}^{-2}$ In these samples the median length was less than $9.0 \mathrm{~mm}$. The third centre covered a wider area ( 7 stations containing more than 100 larvae $\mathrm{m}^{-2}$ ), and contained larvae with a median length of approximately $10 \mathrm{~mm}$. Subsequent sampling effort was targeted on this patch

During the period 29 Aug to 5 Sep, 12 further surveys were carried out. Eleven of these were patch surveys lasting 6 to $10 \mathrm{~h}$ and containing approximately 10 stations. The remaining one carried out on $2 \mathrm{Sep}$ was a general survey of the western approaches to the Pentland Firth based on a fixed grid of 19 stations. Individual patch surveys were not always successful at delineating the

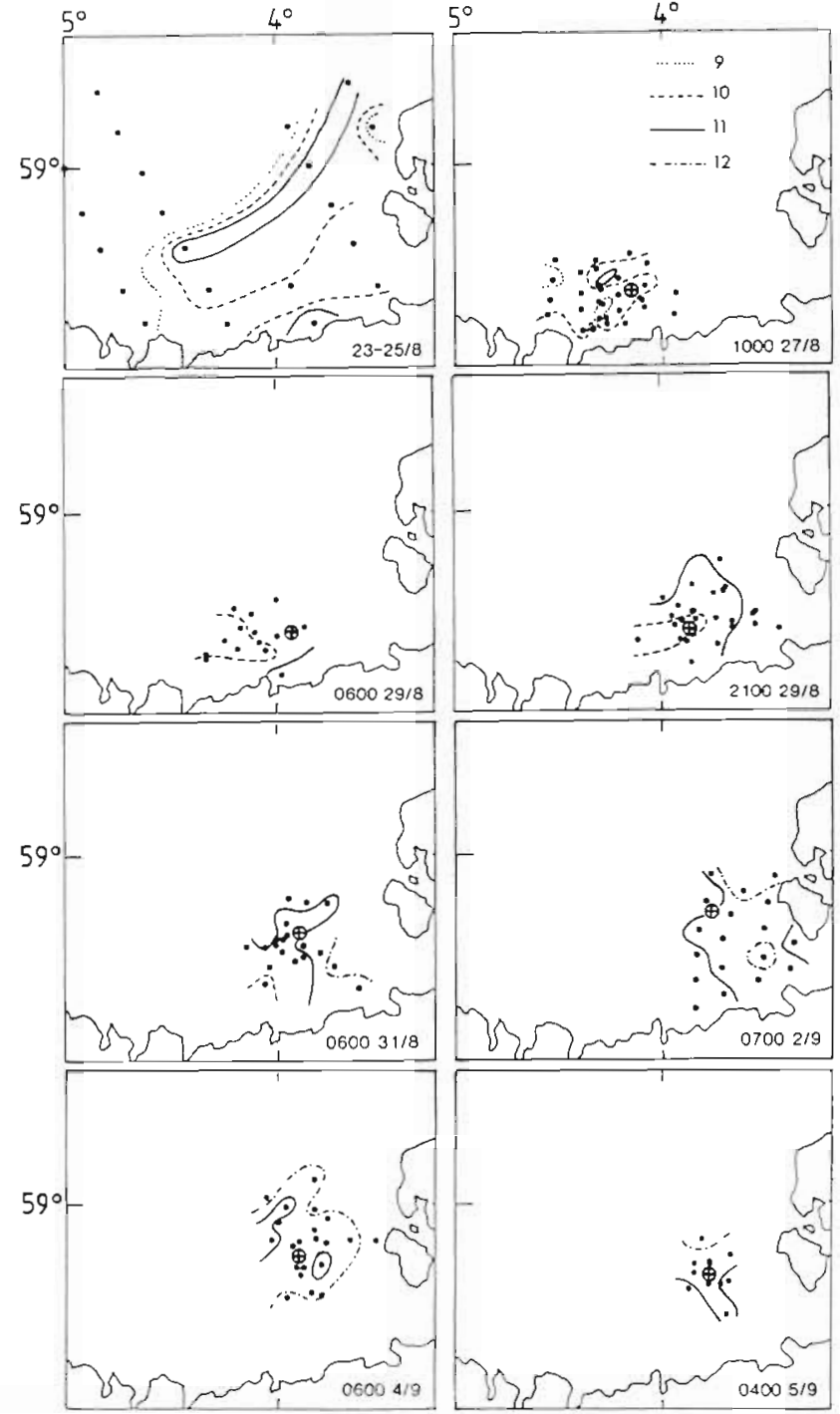

Fig. 6. Clupea harengus. Median lengths of herring larvae samples collected during surveys carried out between 23 Aug and 5 Sep 1985. Except for the first survey, all sampling positions have been corrected for tidal displacement during the surveys. $(\oplus)$ Centre of mass on each coverage

target patch of larvae, but by combining 2 or 3 consecutive surveys spanning a total period of not more than $20 \mathrm{~h}$ and correcting all positions for tidal displacement, a number of good synoptic coverages of the patch were obtained. Details of the coverages are given in Table 1 . and the data are presented in Fig. $5 \& 6$. The coverages did not always completely enclose the centre of the patch (e.g. the first coverage on $29 \mathrm{Aug}$ ) but taken together the concentration distributions and median length data indicate that the same patch of larvae was sampled on each occasion.

The location of the patch centre at the tidal reference time for each coverage was calculated as the centre of mass of the larvae concentration data, excluding stations 
Table 1. Details of surveys and coverages of herring larvae patches (times GMT)

\begin{tabular}{|c|c|c|c|c|c|c|c|}
\hline Coverage & \multicolumn{2}{|c|}{$\begin{array}{l}\text { Tidal correction } \\
\text { reference time }\end{array}$} & \multicolumn{3}{|c|}{ Component surveys } & \multirow{2}{*}{$\begin{array}{c}\text { No. of stations } \\
21\end{array}$} & Duration \\
\hline 1 & \multicolumn{2}{|c|}{ Not applicable } & $0820 \mathrm{~h}$ & $23 \mathrm{Aug}-1127 \mathrm{~h}$ & 25 Aug & & $51 \mathrm{~h} \quad 07 \mathrm{~min}$ \\
\hline 2 & $1000 \mathrm{~h}$ & $27 \mathrm{Aug}$ & $\begin{array}{l}1125 \mathrm{~h} \\
0445 \mathrm{~h}\end{array}$ & $\begin{array}{l}27 \text { Aug }-0417 \mathrm{~h} \\
28 \mathrm{Aug}-0532 \mathrm{~h}\end{array}$ & $\begin{array}{l}28 \mathrm{Aug} \\
28 \mathrm{Aug}\end{array}$ & $\begin{array}{r}28 \\
3\end{array}$ & $\begin{array}{rl}16 \mathrm{~h} & 42 \mathrm{~min} \\
0 \mathrm{~h} & 47 \mathrm{~min}\end{array}$ \\
\hline 3 & $0600 \mathrm{~h}$ & $29 \mathrm{Aug}$ & $\begin{array}{l}0650 \mathrm{~h} \\
1218 \mathrm{~h}\end{array}$ & $\begin{array}{l}29 \text { Aug }-1124 \mathrm{~h} \\
29 \text { Aug }-2036 \mathrm{~h}\end{array}$ & $\begin{array}{l}29 \mathrm{Aug} \\
29 \mathrm{Aug}\end{array}$ & $\begin{array}{l}5 \\
9\end{array}$ & $\begin{array}{ll}4 \mathrm{~h} & 34 \mathrm{~min} \\
8 \mathrm{~h} & 18 \mathrm{~min}\end{array}$ \\
\hline 4 & $2100 \mathrm{~h}$ & 29 Aug & $\begin{array}{l}2145 \mathrm{~h} \\
0419 \mathrm{~h} \\
1026 \mathrm{~h}\end{array}$ & $\begin{array}{l}29 \text { Aug }-0320 h \\
30 \text { Aug }-0932 h \\
30 \text { Aug }-1650 h\end{array}$ & $\begin{array}{l}30 \text { Aug } \\
30 \text { Aug } \\
30 \text { Aug }\end{array}$ & $\begin{array}{l}8 \\
7 \\
9\end{array}$ & $\begin{array}{ll}5 \mathrm{~h} & 35 \mathrm{~min} \\
5 \mathrm{~h} & 13 \mathrm{~min} \\
6 \mathrm{~h} & 24 \mathrm{~min}\end{array}$ \\
\hline 5 & $0600 \mathrm{~h}$ & $31 \mathrm{Aug}$ & $\begin{array}{l}0610 \mathrm{~h} \\
1031 \mathrm{~h} \\
1845 \mathrm{~h}\end{array}$ & $\begin{array}{l}31 \text { Aug }-0918 h \\
31 \text { Aug }-1536 h \\
31 \text { Aug }-2009 h\end{array}$ & $\begin{array}{l}31 \text { Aug } \\
31 \text { Aug } \\
31 \text { Aug }\end{array}$ & $\begin{array}{l}6 \\
9 \\
5\end{array}$ & $\begin{array}{ll}3 \mathrm{~h} & 08 \mathrm{~min} \\
5 \mathrm{~h} & 05 \mathrm{~min} \\
1 \mathrm{~h} & 24 \mathrm{~min}\end{array}$ \\
\hline 6 & $0700 \mathrm{~h}$ & 2 Sep & $0716 \mathrm{~h}$ & 2 Sep $-1804 h$ & $2 \mathrm{Sep}$ & 18 & $10 \mathrm{~h} 48 \mathrm{~min}$ \\
\hline 7 & $0600 \mathrm{~h}$ & $4 \mathrm{Sep}$ & $\begin{array}{l}0610 \mathrm{~h} \\
1427 \mathrm{~h}\end{array}$ & $\begin{array}{l}4 \text { Sep }-1356 h \\
4 \text { Sep }-1923 h\end{array}$ & $\begin{array}{l}4 \text { Sep } \\
4 \text { Sep }\end{array}$ & $\begin{array}{r}12 \\
9\end{array}$ & $\begin{array}{ll}7 \mathrm{~h} & 46 \mathrm{~min} \\
4 \mathrm{~h} & 56 \mathrm{~min}\end{array}$ \\
\hline 8 & $0400 \mathrm{~h}$ & $5 \mathrm{Sep}$ & $0420 \mathrm{~h}$ & 5 Sep $-0954 h$ & 5 Sep & 11 & $5 \mathrm{~h} 34 \mathrm{~min}$ \\
\hline
\end{tabular}

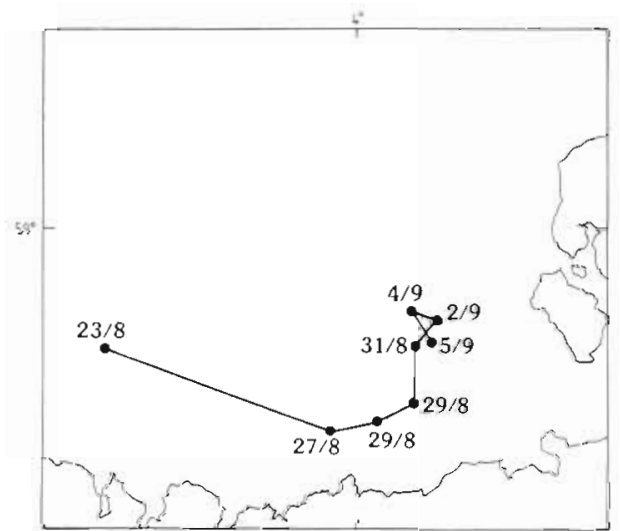

Fig. 7. Clupea harengus. Trajectory of the centre of mass of the patch of herring larvae over the period $23 \mathrm{Aug}$ to $5 \mathrm{Sep}$ 1985

considered on the basis of the length frequency distribution to have been taken from other patches. Stations excluded on this basis were the 4 most westerly positions plus those containing larvae with a median length less than $9 \mathrm{~mm}$ on $27 \mathrm{Aug}$, and the 2 western-most stations in the first coverage on 29 Aug. For the general survey data from 23 to 25 Aug, the spatial resolution of the data was insufficient to reasonably define a centre of mass for an individual patch, so the position of the highest concentration measurement was taken as an estimate of the central point of the distribution. The centre of mass need not necessarily be located at the position of the highest cencentration, since it is possible to envisage a situation where horizontal diffusion might vary considerable over the area covered by an individual patch thus distorting

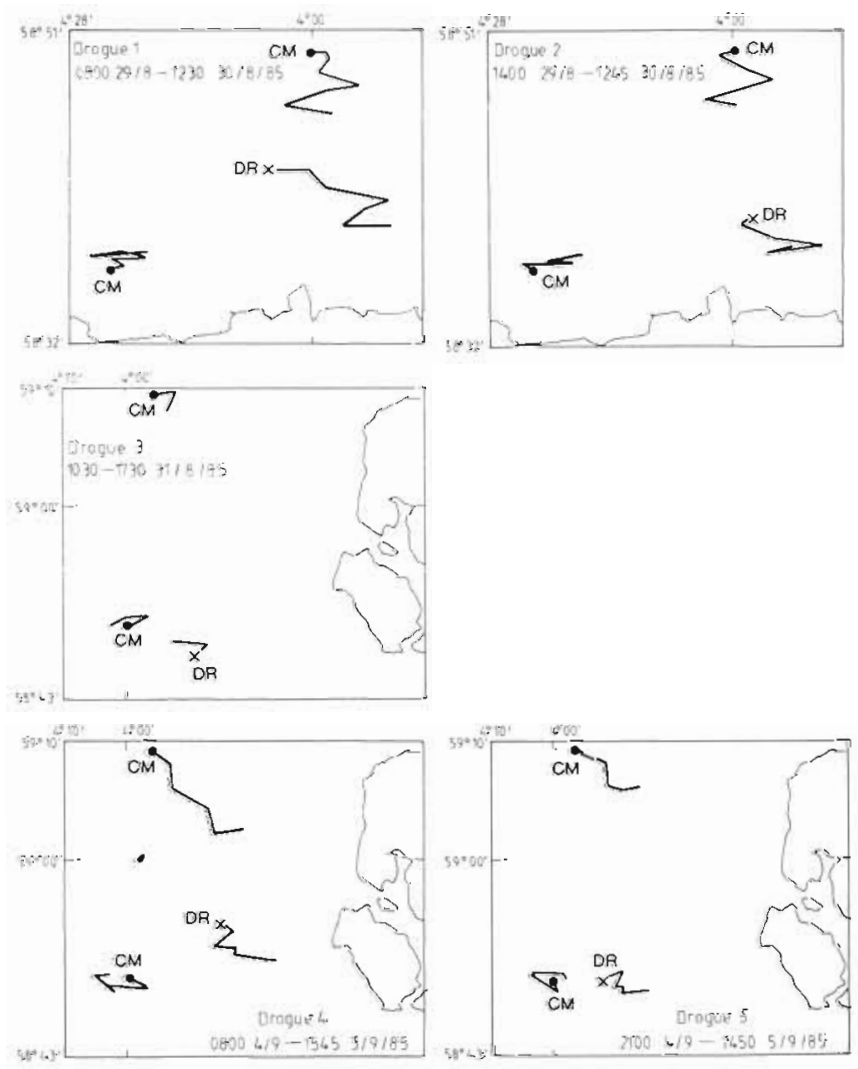

Fig. 8. Trajectories of drogues released off the north coast of Scotland between $29 \mathrm{Aug}$ and 4 Sep 1985. The equivalent trajectories at current meter mooring positions were constructed from 1 h mean current velocity data. CM: current meter; DR: drogue 


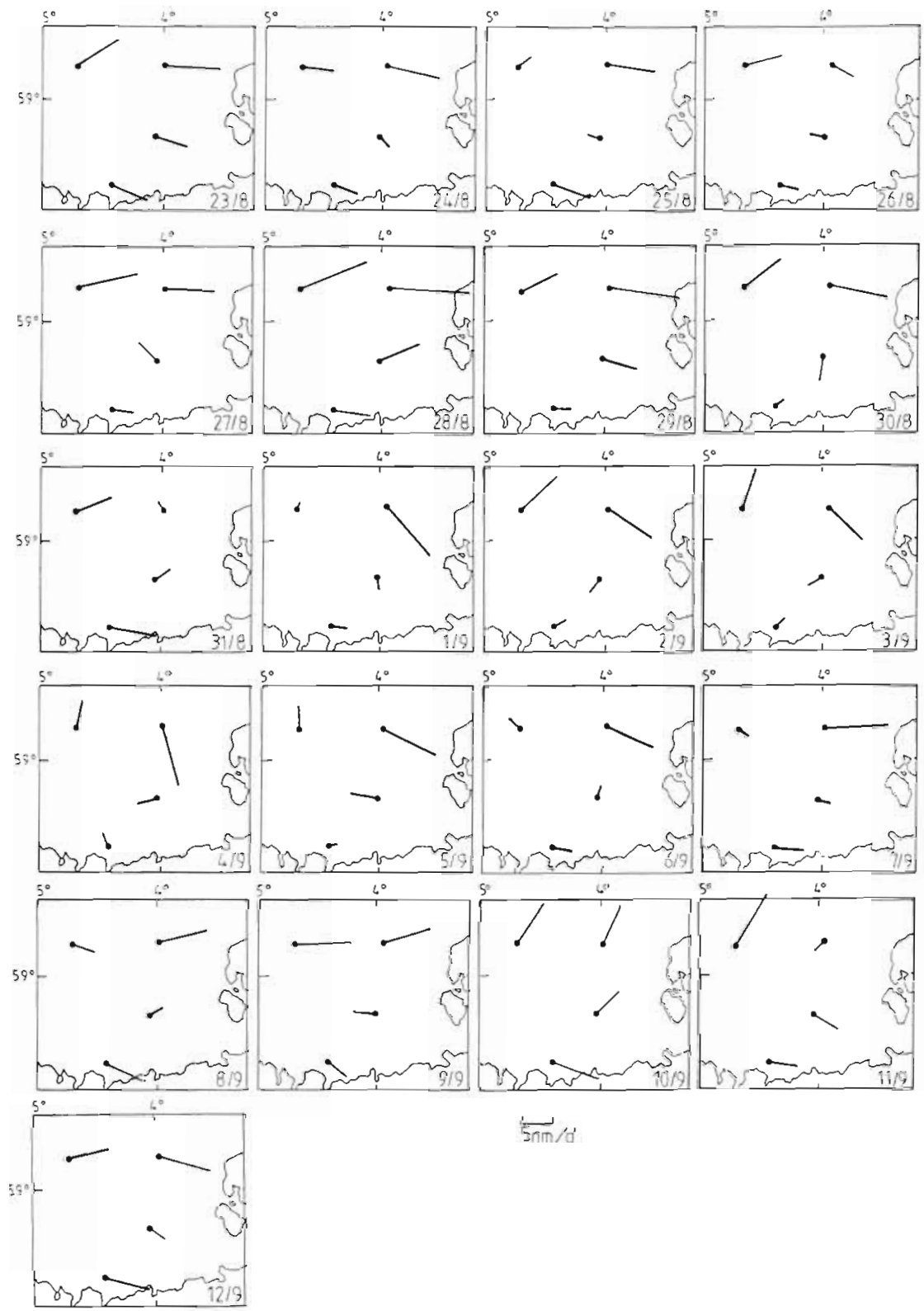

Fig. 9. Residual currents over 2 tidal cycles ( $25 \mathrm{~h}$ ) at each of 4 moorings off the north coast of Scotland for the period 23 Aug to 12 Sep 1985

the distribution of concentrations but not necessarily affecting the centre of mass. The trajectory of the patch centre over the entire tracking period is shown in Fig. 7.

\section{Comparison of patch and drogue trajectories, and current meter records}

Drifting buoys were deployed for periods of up to $32 \mathrm{~h}$ on 3 occasions during the tracking period. On the first and last occasions a pair of buoys was deployed along a line normal to the drift trajectory of the patch, one close to the centre and the other well outside the patch. The positions of the buoys were recorded at irregular intervals by steaming up to them and noting the ship's position. The trajectories do not therefore represent full tidal current ellipses, but a series of 'snapshot' observations during the tidal cycle.

In general, the drifting buoys gave quite good accounts of the short-term movements of the patch of larvae (Fig. 8). However, the predicted trajectories constructed from $1 \mathrm{~h}$ mean current velocities recorded at the 2 nearest current meter moorings in each case are less easy to reconcile (Fig. 8). The current meters and 


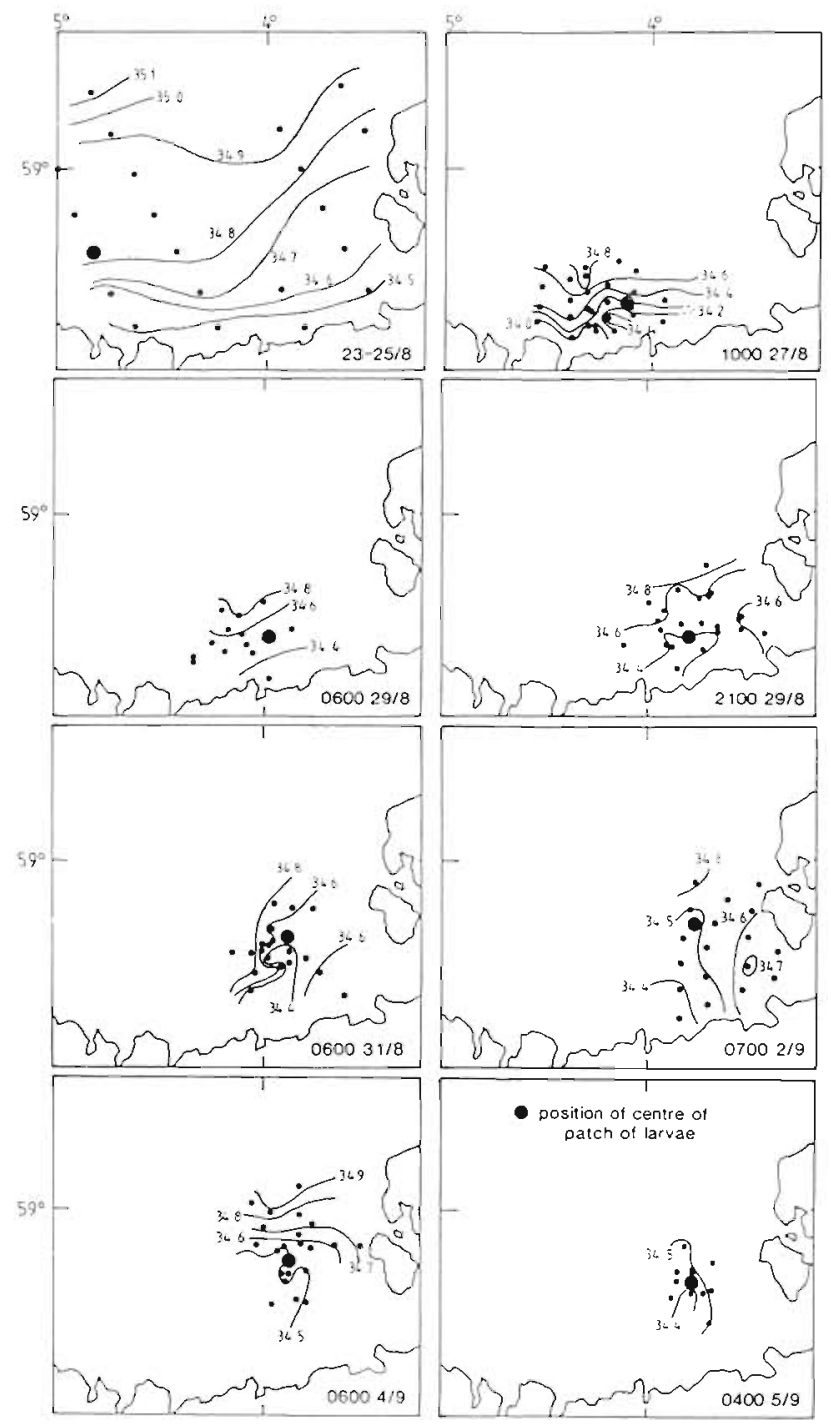

Fig. 10. Distributions of surface salinity during surveys carried out between 23 Aug and 5 Sep 1985. Except for the first survey, all data were collected with a thermosalinograph and have been corrected for tidal displacement during the survey. During the first survey data were collected using water bottles

buoys are in good agreement during deployments between 29 and 31 Aug, close to the north coast of Scotland. However, the buoys deployed on 4 and 5 Sep followed a trajectory which bore little resemblance to currents at the nearest adjacent mooring but were very similar to trajectories at the current meter positioned to the north close to the centre of the main offshore current stream. An interpretation of this observation is that the pattern of circulation in the deep trough immediately west of Orkney (Fig. 1) changed between $31 \mathrm{Aug}$ and 5 Sep and that this had an important effect on the drift trajectory of the patch of larvae. This interpretation is confirmed by an examination of the changes in $25 \mathrm{~h}$ residual currents at each of the 4 moorings over the tracking period (Fig. 9). The circula-

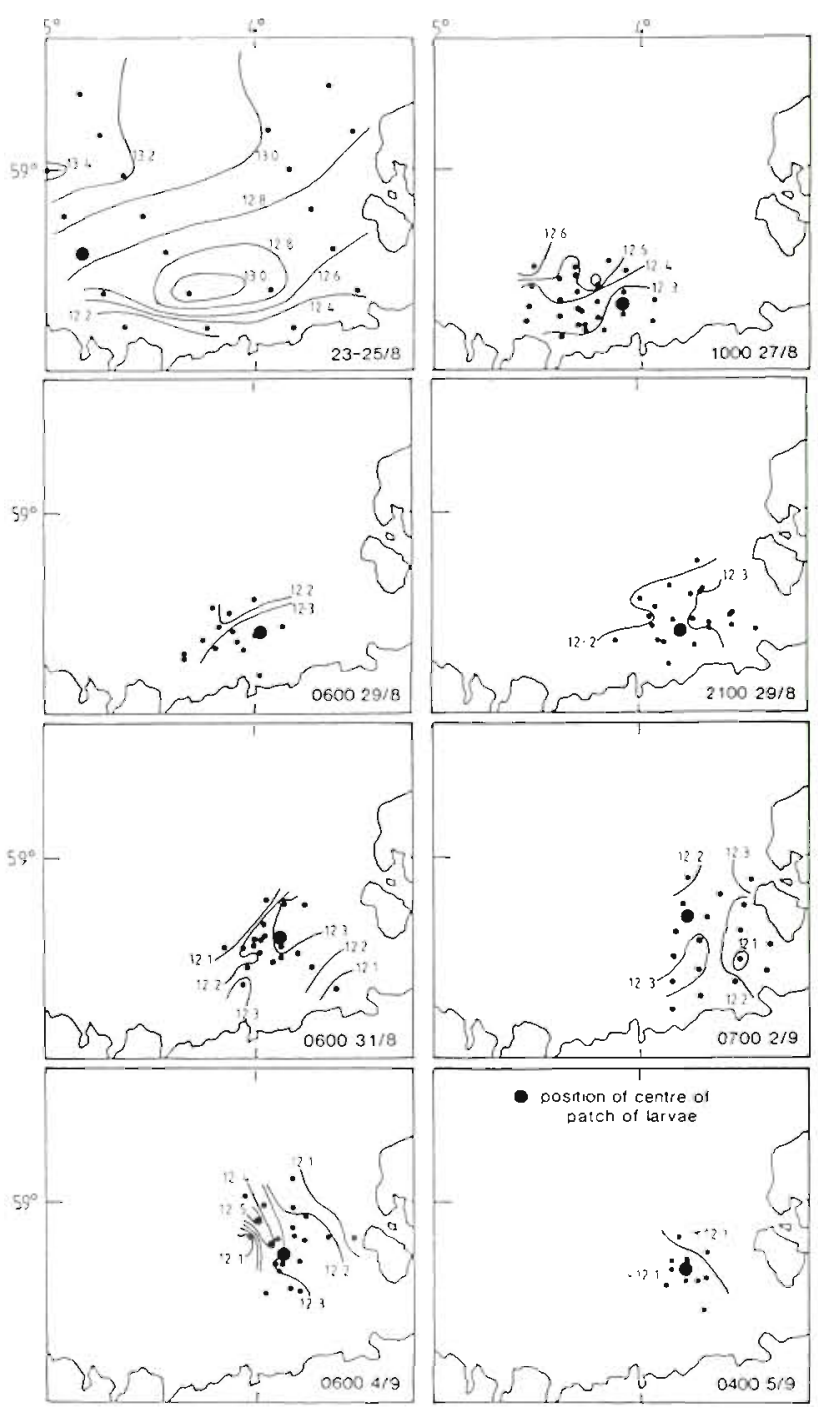

Fig. 11. Distributions of surface temperature during surveys carried out between 23 Aug and 5 Sep 1985. Except for the first survey, all data were collected with a thermosalinograph and have been corrected for tidal displacement durinc the survey. During the first survey data were collected using water bottles

tion pattern conformed to the long-term mean (Fig. 3) over the first half of the period, but from 1 to 5 Sep the pattern was seriously disturbed and a cyclonic gyre developed which affected all current meters on 4 Sep. The reversal of flow in the deep trough immediately west of Orkney at this time is entirely consistent with the reversal of the northerly drift of the patch of larvae and with the observed relationships between the drogue trajectories and current meter records.

The precise environmental conditions leading to the dramatic switch in circulation pattern in the inshore waters are not known, but a preliminary analysis suggests that the incidence of northerly winds is a major factor. A detailed analysis of this relationship will be presented elsewhere. 


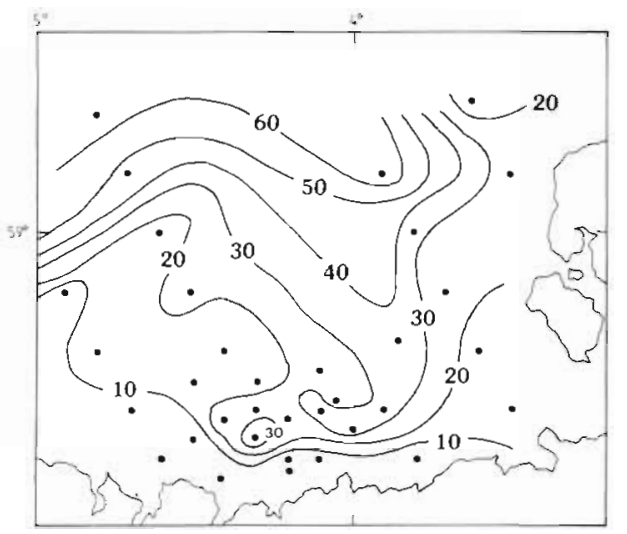

Fig. 12. Distribution of the stratification parameter $\left(\phi, \mathrm{J} \mathrm{m}^{-3}\right)$ off the north coast of Scotland between 23 and 25 Aug 1985
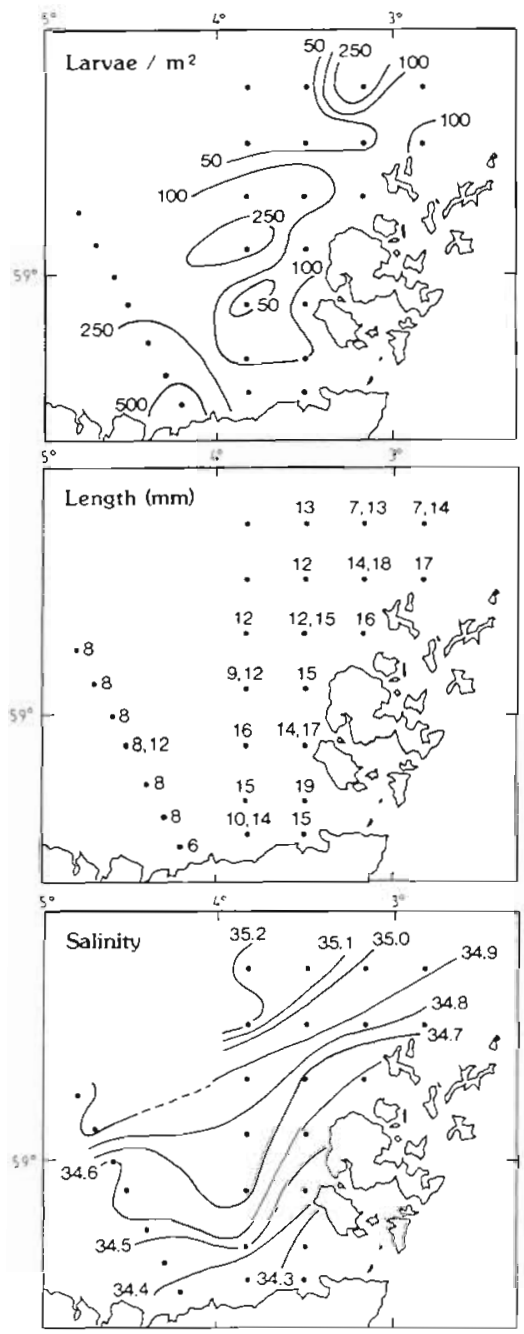

Fig. 13. Distributuon of herring larvae Clupea harengus and surface salinity dunng a survey carried out by FRV Scotia from 12 to 13 Sep 1985. (a) Concentration of herring larvae number $\mathrm{m}^{-2}$ ). (b) Modes of length distributions of herring larvae. (c) Surface salinity

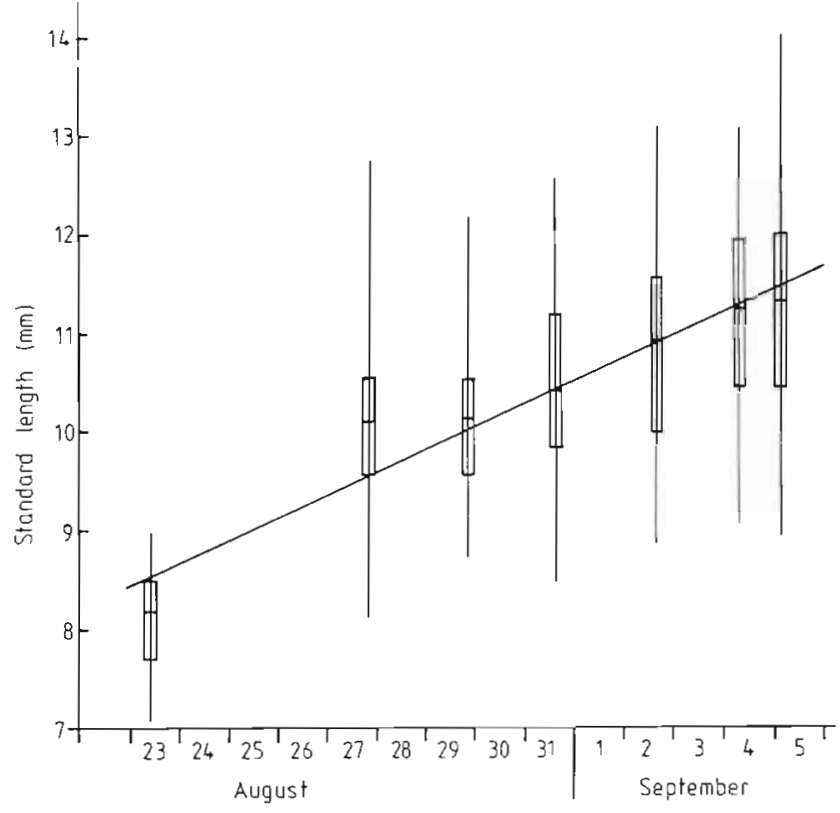

Fig. 14. Clupea harengus. Length distributions of herring larvae at the centre of the patch over the period 23 Aug to 5 Sep 1985. The median, hinges and extremes of the distributions are shown for the sample collected closest to the patch centre on each survey. Linear regression of the median lengths against time gives an estimate of the growth rate of $0.25 \mathrm{~mm} \mathrm{~d}^{-1}$

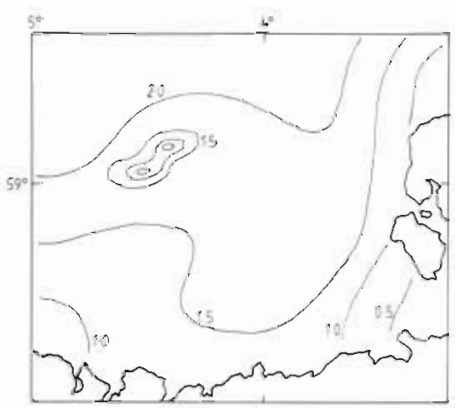

Fig. 15. Approximate distribution of the Simpson-Hunter stratification parameter $\left(\log _{10} \mathrm{~h} / \mathrm{u}^{3}\right)$. Values of the parameter are inversely related to tidal mixing intensity. Data on maximum tidal current speed (u) were taken from Ellett \& Edwards (1983) and water depth (h) was as shown in. Fig. 1

\section{Comparison of patch trajectory and physical hydrographic variables}

Surface salinity and temperature were measured continuously throughout the tracking experiment. The distributions of these variables after tidal correction of sampling positions during each coverage of the patch are shown in Fig. 10\& 11 These data, in particular the surface salinity, provide confirmation of the drift trajectory of the patch of larvae.

During the general survey (23 to $25 \mathrm{Aug}$ ) no surface 
salinities less than 34.4 ppt were encountered. However, during the first patch coverage a plume of low salinity water ( $<34.2 \mathrm{ppt}$ ) emanating from a sea loch on the north coast was detected. At this time, herring larvae were located on the offshore edge of the plume. The distribution of surface salinity during subsequent coverages of the patch of larvae indicates that both the larvae and the plume of run-off water were subject to the same transport processes during the tracking period. The centre of the patch remained approximately in association with the $34.5 \mathrm{ppt}$ surface isohaline throughout the experiment.

The changes in circulation regime between 31 Aug and 5 Sep indicated by the drifting buoy and current meter data are also supported by the surface salinity data. Up to and including 31 Aug the plume was carried along the deep trough west of Orkney, and a strong surface salinity gradient developed along its western boundary. However, by 4 Sep the northerly transport had ceased, being blocked by the inflow of high salinity water (> $34.8 \mathrm{ppt}$ ) from the north. At this stage, the $34.9 \mathrm{ppt}$ isohaline was situated very much further southeast than during the general survey on 23 to $25 \mathrm{Aug}$.

The surface temperature data provide a less concise account of the advection in the area since the low salinity plume was of a similar temperature to the surrounding water. However, the general pattern of the data is very similar, particularly with respect to the influx of water from the north on 4 Sep.

The distribution of the water column stratification parameter (Fig. 12) indicates that at the time of the experiment, the water in the trough west of Orkney was more stratified than the surrounding inshore areas. The drift trajectory of the larvae and of the low salinity plume ran approximately along the line of the $20 \mathrm{~J} \mathrm{~m}^{-3}$ isopleth.

\section{Long-term implications of circulation pattern}

The circulation regimes for the $7 \mathrm{~d}$ following the end of the tracking period are shown in Fig. 9. These data suggest that the cyclonic gyre detected on 4 Sep was a short-lived phenomenon and that by 7 Sep the more usual circulation pattern had been re-established. If the previous northerly drift rate of the patch of larvae was maintained under these circumstances than the patch could have been carried to the northwest of the Orkney Isles by 12 Sep. On this date, a survey of the area was carried out from FRV Scotia as part of the ICES International Herring Larvae Survey. The distribution of herring larvae and surface salinity during this survey are shown in Fig. 13. The distance between sampling positions in the ICES survey ( $10 \mathrm{n}$ mile) is such that it is not possible to identify the patch of larvae studied during the tracking experiment. However, a number of observations support the conclusion that the patch was carried north along the west side of the Orkney Isles after $5 \mathrm{Sep}$. First, if the growth rate of larvae in the patch $\left(0.25 \mathrm{~mm} \mathrm{~d}^{-1}\right.$; Fig. 14) was maintained then the median length on 12 Sep would have been approximately $12.5 \mathrm{~mm}$. High concentrations of larvae were caught close inshore along the north coast of the mainland and to the southwest of Orkney but none of these catches had length distributions with modes anywhere near $12.5 \mathrm{~mm}$ and it is therefore most unlikely that the tracked patch was carried south or southeast after 5 Sep. Secondly, water with a surface salinity less than 34.7 ppt was found along the entire western side of the Orkney Isles on 12 Sep, extending substantially further north than on 23 to $25 \mathrm{Aug}$. This suggests that the plume of low salinity water observed during the tracking experiment was carried north to approximately $59^{\circ} 15^{\prime} \mathrm{N}$ during the period 5 to 12 Sep. Finally, the catches of herring larvae in low salinity water at approximately $59^{\circ} 15^{\prime} \mathrm{N}$ are the only ones in the entire survey area with length modes in the range 12 to $13 \mathrm{~mm}$.

Examination of the circulation patterns over the tracking period (Fig. 9) suggest that the 25 h residual current vector at the most southerly mooring is a good indicator of the state of circulation in the whole area. Weak flow, or flow in a north or northwesterly direction at this position, are indicative of current reversal in the deep trough and the development of a cyclonic gyre in the area. The records from the entire 3 mo deployment of the mooring suggest that current reversal occurred on only one other occasion during this period (22 to 24 Sep).

\section{DISCUSSION}

The results of the investigations indicate a very complex circulation and larval transport system in the inshore waters off the north coast of Scotland. This is a radically different situation to that encountered to the west of the Hebrides during a similar exercise carried out in 1984 (Heath \& MacLachlan 1987). In the Hebrides study the dispersion of a patch of yolk-sac larvae could be modelled using a lateral shear-diffusion model and mortality in the population of larvae estimated from the decrease over time of the integral of a bi-variate normal distribution of concentrations. It is probably not valid to use such a model to analyse the data collected off the north of Scotland since lateral turbulent diffusion is almost certainly not constant over the area. This is evident from the observations on 2 Sep (Fig. 5) where the southern end of the patch is more diffuse than the northern end. This can be accounted for by the variations in the Simpson/Hunter stratification parameter $\log _{10} \mathrm{~h} / \mathrm{u}^{3}$ (Fig. 15) which is inversely related to tidal mixing intensity (Simpson \& Hunter 1974) and hence the coefficient of turbulent diffusion $(\mathrm{h}=$ water depth; $\mathrm{u}=$ maximum tidal current 
speed). In this case the mixing intensity increases with proximity to the entrance of the Pentland Firth.

The tracked patch clearly did not enter the Pentland Firth during the experiment and it is unlikely that it did so subsequently. However, the distribution of larvae on 12 Sep suggests that larvae do enter the Firth but probably only from areas close inshore off the north coast. The samples of larvae from the Pentland Firth had substantially larger median lengths than those from surrounding waters, and an examination of data from the ICES Herring Larval Surveys in previous years indicates that this has frequently been the case in the past. The water in the Firth is invariably of very different salinity to that found either to the east or to the west, and we have never found any evidence of continuity through the Firth between the waters on either side. These observations suggest that residual flow through the Pentland Firth is insignificant compared to transport rates in more open waters, although the tidal displacement is certainly very large. However, the diffusion flux through the Firth is probably greater than in surrounding waters on account of the tidal mixing, but based on observations of the length distributions, any larvae entering the area by diffusion are likely to be retained for several weeks.

The data from the standard survey line indicate that the breakdown of thermal stratification in the survey area, as indicated by the difference in surface temperature between inshore and offshore regions, coincided with a decrease in salinity and an increase in zooplankton biomass. Peak hatching of herring larvae in the inshore region coincided with this period. Hatching had clearly ceased in the inshore area by the end of September since no more small $(<9 \mathrm{~mm}$ ) larvae were caught but high concentrations of large $(>15 \mathrm{~mm})$ larvae $\left(>100 \mathrm{~m}^{-2}\right)$ persisted at the stations closest to the coast until late November, indicating a long residence time or slow through-flow of larvae in the inshore region. Further offshore, larvae were rapidly transported out of the area after the peak hatching period. We have some evidence that the persistence until late in the year of high concentrations of larvae close to the coast is a recurrent feature of this area, since similar results were obtained during a survey carried out by the Marine Laboratory in November and December 1978 (unpubl. data).

The investigations show that the deep trough on the west side of the Orkney Isles is of considerable importance to the circulation of the inshore waters off the north coast. The long-term average vector from the current meter moored at the northern end of the trough indicates that the main flow normally passes across the opening and then turns sharply north to follow the $100 \mathrm{~m}$ isobath around the north of Orkney. Under these circumstances the residual flow in the trough is weak and northerly However, certain as yet unidentified meteorological events cause the offshore current to penetrate more deeply into the trough. Under extreme circumstances a reversal of the residual flow in the trough may result, such as occurred on 4 Sep, leading to a cyclonic flow around the shallow banks associated with Sule Skerry and retention of larvae in the inshore area. During the period studied in detail, a patch of larvae was clearly retained for at least $2 \mathrm{wk}$. We cannot be certain what happened to the patch after the tracking period but it seems likely that it escaped to the north and passed to the northwest of Orkney. However, if the current reversal had persisted, then the larvae uld probably have been carried to the southwest and retained in the area for very much longer.

'Advection failure', i.e. the failure of current system to deliver larvae to nursery areas, is strongly implicated as an origin of recruitment failure in North Sea herring stocks (Corten 1986). Heath (1984) and MacKenzie (1985) demonstrated by means of intestinal parasite fauna studies that the spawning population of herring on the west coast of Scotland relies upon juvenile populations in the eastern North Sea for approximately $70 \%$ of it's recruits aged $3 \mathrm{yr}$, the remainder being derived from Scottish coastal waters. Assuming that the recruitment migrations represent a homing of fish to their parental spawning area (an assumption supported by the interannual consistency of morphometric variations [Harden Jones 1970]), then the retention of larvae off the north coast of Scotland, rather than transport into the North Sea through entrainment into the Fair Isle Inflow, may have significance for the subsequent composition and success of the year class.

Acknowledgements. We are grateful to the officers and crew of FRV Clupea and to the numerous colleagues who have contributed to this work. In particular, we thank R. D. Adams and $D$. Baird for their assistance at sea and in the laboratory. Thanks also to $G$. Slesser and $E$. Henderson for assistance with hydrographic data analysis, and N. Nicoll and C. Blanpied for the analysis of plankton samples and herring larvae measurement respectively.

\section{LITERATURE CITED}

Anon. (1975). Report of the ICES Working Group on the Bløden tagging experiment 1969-1970. ICES Coop. Res. Rep. 47: 1-137

Bakum, A. (1985). Comparative studies and the recruitment problem. Calcofi. Rep. 26: 30-40

Corten, A. (1986). On the causes of recruitment failure of herring in the central and northern North Sea in the years 1972-1978. J. Conseil 42: 281-294

Craig, R. E. (1959). Hydrography of Scottish coastal waters. Mar. Res. 2: 1-30

Dooley, H. D. (1974). A comparison of drogue and current meter measurements in shallow waters. Rapp. P.-v.-Réun. Cons. int. Explor. Mer 167: 225-230

Dooley, H. D. (1981). The role of axially varying vertical 
mixing along the path of a current in generating phytoplankton production. Phil. Trans. R. Soc. A302: 649-660

Dooley, H. D., McKay, D. W (1975). Herring larvae and currents west of Orkney. Count. Meet. int. Coun. Explor. Sea C.M.-ICES/H: 43 Pelagic Fish Committee (mimeo)

Ellett, D. J., Edwards, A. (1983). Oceanography and inshore hydrography of the Inner Hebrides. Proc. R. Soc. Edinb. 83 B: $143-160$

Gehringer, J. W. (1952). An all metal plankton sampler (model Gulf III). Spec. scient. Rep. U.S. Fish Wildl. Serv. 88: 7-12

Harden Jones, F. R. (1970). Fish migration. Edward Arnold London

Heath, M. R. (1984). Report on an acoustic survey carried out in the northern part of Divison VIa on herring and mackerel Count. Meet. int. Coun. Explor. Sea C.M.-IC.ES/H: 62 Pelagic Fish Commitee (mimeo)

Heath, M. R., Henderson, E. W., Hopkins, P. J., Martin, J. H. A., Rankine, P. W. (1985). Hydrographic influences on the distribution of herring larvae in the Orkney-Shetland area. Count. Meet. int. Explor. Sea C.M.-ICES/H: 29 Pelagic Fish Committee (mimeo)

Heath, M. R., Mac Lachlan, P. (1987). Dispersion and mortality of yolk-sac herring (Clupea harengus L.) larvae from a spawning ground to the west of the Outer Hebrides. J. Plankton Res. 9 (4); 613-630

Heath, M. R., Walker, J. (1987). A preliminary study of the drift of larval herring (Clupea harengus L.) using gene frequency data. J. Cons. int. Explor. Mer 43: 139-145

Johnston, R., Craig, R. E. (1953). Hydrographic conditions off the north coast of Scotland. J. Cons. int. Explor Mer 42: 33-64

MacKenzie. K. (1985). The use of parasites as biological tags in population studies of herring (Clupea harengus L.) in the North Sea and to the north and west of Scotland. J. Cons. int. Explor. Mer 42: 33-64

Ramster, J. W., Doddington, T C., Horwood, J. W. (1973). An assessment of water movements in the northern North Sea and off the north coast of Scotland in September 1972 Count. Meet. int. Coun. Explor. Sea C.M.-ICES/C: 2 Hydrography Committee (mimeo)

Rankine, P. W. (1986). Herring spawning grounds around the north of Scotland. Count. Meet. int. Coun. Explor. Sea C.M.-ICES/H: 15 Pelagic Fish Committee (mimeo)

Simpson, J. H., Hunter, J. R. (1974). Fronts in the Irish Sea. Nature Lond. 250: 404-406

Simpson, J. H., Pingree, R. D. (1978). Shallow sea fronts produced by tidal stirring. In: M. J. Bowman, Esaias, W. E. (ed.) Oceanic fronts in coastal processes. Springer-Verlag, Berlin, p. 29-42

Wood, R. J. (1971). Report on the international surveys of herring larvae in the North Sea and adjacent waters, 1969/ 70. ICES Coop. Res. Rep. Ser. A, No. 22: 3-36

Wood, R. J., Nichols, J. H. (1983). Further comparative data on herring larvae caught by English and Dutch highspeed plankton samplers, together with results of a flume calibration of the Dutch sampler. Count. Meet. int. Coun. Explor. Sea C.M.-ICES/H: 9 Pelagic Fish Commitee (mimeo) 